\title{
The Impact of Corporate Governance on Firm Performance: Empirical Study in Vietnam
}

\author{
Duc Hong Vo ${ }^{1,2} \&$ Tri Minh Nguyen ${ }^{3}$ \\ ${ }^{1}$ Economic Regulation Authority, Perth, Australia \\ ${ }^{2}$ Open University of Ho Chi Minh City, Vietnam \\ ${ }^{3}$ School of Development Economic, University of Economics Ho Chi Minh City, Ho Chi Minh City, Vietnam \\ Correspondence: Tri Minh Nguyen, School of Development Economic, University of Economics Ho Chi Minh \\ City, 1A Hoang Dieu street, Ward 10, Phu Nhuan dist., Ho Chi Minh City, Vietnam. Tel: 84-909-959-176. E-mail: \\ tri.nm@vnp.edu.vn
}

Received: March 27, 2014

Accepted: April 14, 2014

Online Published: May 25, 2014

doi:10.5539/ijef.v6n6p1

URL: http://dx.doi.org/10.5539/ijef.v6n6p1

\begin{abstract}
This empirical research for listed firms in Vietnam is conducted to examine the relationship between corporate governance and firm performance. In this study, corporate governance is proxied by a set of variables, including a dual role of the CEO, board's size, board independence and ownership concentration. In addition, firm performance is measured by four different methods which are (i) return on asset (ROA), (ii) return on equity (ROE), (iii) Z-score by Altman (1968) and (iv) Tobin's Q. Using the Feasible Generalized Least Squares (FGLS) on the dataset of 177 listed companies in Vietnam for the period of 5 years, from 2008 to 2012, the findings of this study indicate multiple effects of corporate governance on firm performance. First, duality role of the CEO is positively correlated with firm performance. Second, there is a structural change in relation between managerial ownership and firm performance. Third, board independence has opposite impacts on firm performance. Fourth, this study however fails to provide an empirical evidence support the statistically significant relationship between board size and firm performance.
\end{abstract}

Keywords: corporate governance, firm performance, listed companies, Vietnam

\section{Introduction}

Corporate governance focuses on the structures and processes for the business direction and management of firms. It involves the relationships among company's controlling system, roles of its board directors, shareholders and stakeholders. Williamson (1988) considered that the corporate governance has relation with transaction cost and, in turn, enhances firm performance. In addition, weak corporate governance reduces investor confidence and discourages outside investment. Similarly, Bhagat and Bolton (2008) undertook a research on the endogenous relationship between corporate governance and firm performance and concluded that good corporate governance affects firm performance positively.

In Vietnam, the framework of corporate governance has just been in an early stage of development. In academia, the corporate governance in Vietnam has been approached many angles of law and legal consideration by Nguyen (2008), qualitative consideration by Le and Walker (2008) and quantitative approach by Vo and Phan (2013a, b, c, d). Various empirical studies on corporate governance and firm performance in Viet Nam consecutively conducted by Vo and Phan have confirmed that this important issue in terms of research and practice has not attracted significant attention research community in Vietnam in the past. However, even though Vo and Phan's studies have covered a wide range of issues in relation to corporate governance, their estimation for firms performance is relatively constrained. As a result, the importance of the topic on corporate governance and a relaxation of restriction on the measurements of firm performance has provided key rationales to conduct this study to provide another empirical evidence on the issue for a further debate.

This study uses a sample including listed firms in Ho Chi Minh City Stock Exchange (HOSE). Until 2012, HOSE has 342 listed firms including 301 stocks, 3 institutional fund certificates and 38 bonds. Total volume of share and listed value is more than 26.7 billion shares and 273 trillion VND respectively. The HOSE is considered as a high liquidity market with total market capitalization of 678 trillion VND (32.6 billion USD) by 
the end of 2012. This figure accounted for 24 percent of the national GDP. Moreover, the average of transaction value in 2012 was 890 billion VND, an increase of 39 percent compared to that in 2011 . The specific objective of this study is to examine the relationship between corporate governance and firm performance in term of three components: duality, board composition and ownership concentration using The Feasible Generalized Least Square (FGLS). From the sample, bank and financial institutions are excluded.

The structure of this paper includes five sections. Following this section, section 2 is devoted for a literature review exploring the theories explaining the mechanism of impact of corporate governance on firm performance, as well as the relationship between them. The next section focuses on descriptions of data collection, measurements of model variables and regressions. Section 4discusses empirical results on the effects of corporate governance on firm performance in Vietnam from 2008 to 2012. The final section summarizes main findings, provides implications for firms in Vietnam on corporate governance and firm performance.

\section{Literature Review}

\subsection{Theoretical Considerations}

In corporate governance, board of director is considered as the most important factor which affects an entire business and interest of owners. As such, the question of "what is the board of director characteristics and how does it influence firm performance of a firm" has attracted significant attention from academia and practitioners over the last 50 years or so. Zahra and Pearce (1989) in their research approached the role of board of director on financial performance by reviewing and synthesizing four perspectives: (i) legalistic perspective, (ii) resources dependence, (iii) class hegemony; and (iv) agency theory. Meanwhile, stewardship theory, which is developed by Davis, Schoorman and Donaldson (1997), explained the board's role in different way.

\subsubsection{Legalistic Perspective}

Zahra and Pearce (1989) defined corporate governance as the contribution of four factors including board composition, characteristics, structure and process. This theory also indicated that the efficiency of board director is determined by two primary factors known as service and control: improving company reputation, cooperating with external environment; ensuring sustainable corporate growth rate and serving shareholder's interest. These two roles depend on ownership concentration and firm size. The ownership concentration refers to the size of owners which impacts to the survival and firm's wealth.

\subsubsection{Resource Dependence}

This perspective was developed based on sociological and organizational theory. Zahra and Pearce (1989) pointed out that the directors play an important role to handle general and competitive environment. The advantages which directors bring to firms are to reduce uncertainty in business, to improve company reputation in society and considered as a transaction cost. Hillman and Dalziel (2003) presented that resources dependence theory is also crucial path exploring the impact of the board on firm performance. Resources dependence impacts on firm performance through increasing the strong relationship between organization and external contingencies, decreasing transaction cost and rejecting uncertain situation.

\subsubsection{Class Hegemony}

Class hegemony considers board process as important factor affecting firm performance. Similarly with legalistic approach, Zahra and Pearce (1989) presented that board process is an important variable to investigate the relationship between board of directors and firm performance. According to this theory, service and control depend on ownership concentration, CEO power and style. CEO is considered as the most important person serving the board.

\subsubsection{Agency Theory}

This theory is considered as a dominant role to explain the role of board directors on firm performance. Zahra and Pearce (1989) reviewed research papers and synthetized them into main rule in order to explore this relationship. In term of agency theory, the principal and agent are shareholders and directors respectively. Their theory presented that there is inconsistency between the benefit of owners and managers based on the attributes of four characteristics as discussed legalistic perspective. Having similar view with Zahra and Pearce (1989) on agency theory, Davis, Schoorman and Donaldson (1997) indicated more clearly that agency theory refers to the conflict between the goal of principal as owners and agent as managers. In a particular company, shareholders allocate their wealth investing on the asset of corporations and they authorize managers to operate the firms. The principal has tendency to maximize the utility of shareholder in the long- run. By contrast, the agents usually operate firms for their individual interests. Pfeffer (1972) indicated that most companies meet the change in 
business environment is changing size and board composition measured by percentage of outside directors and ownership. The percentage of outside director helps firms attract outside capital which also influences the firm performance. With external capital, the firm can take advantage of cheaper capital from the outside and reduce costs. In addition, organizational environment is also reflected through a board size. The advantages of larger size board are first, more diversified in handling problems and second, increasing the impact of company to society due to the relationship of members in board. Therefore, firms with many directors will exploit more resources from the outside than the others in order to make their performance better.

\subsubsection{Stewardship Theory}

In contrast to agency theory, Davis, Schoorman and Donaldson (1997) examined the new approach to the relationship between the benefit of shareholders and managers, which is developed based on psychological and sociological concepts. The interests of individual and organization are mixed and managers operate companies to maximize utility. The cooperative behaviors are not traded off for self-behaviors because, in term of stewardship theory, the thoughts and activities of directors are consistent with the performance of companies. Therefore, the steward seeks to get the objectives and development of firms. The differences between the stewardship and agency are that the agency theory focuses on extrinsic satisfaction which can be measured by market value and the other refers to intrinsic satisfaction which can be motivation, achievement or reputation. Moreover, the manager in stewardship perspective realizes that by working for the high performance of organization, the personal utility can be met. Additional new information from this theory is focusing on the role of structure rather than the monitor and control. Particularly, stewardship concepts consider structure of the board affecting the firm performance significantly.

\subsection{Empirical Studies}

\subsubsection{CEO Duality and Firm Performance}

The role of CEO-chair person is also clarified by Rechner and Dalton (1991) through longitudinal analysis. They conducted their study in two group companies having a change in board of director and how it affects corporate performance. The study pointed out that there is significant difference in return on investment (ROI), return on equity (ROE) and profit margin between CEO duality firms and those with independent directors. The direction and magnitude of duality-performance relationship are presented again in study of Boyd (1995). He used contingency model to test two theories: agency theory and stewardship theory and presented that the effect of chair directors on firm performance is very different across various environments. The kinds of environment are separated in three sectors: munificence, dynamism and complexity. The munificence which measures the available level of resources supporting to industry prevents firms from uncertain situation. Dynamism reflects changing degree of environment whereas complexity measures inequalities among competitors. Boyd (1995) suggested that there is an occurrence of incompletion and misleading in both agency theory and stewardship theory. However, through the effect of uncertain environment, CEO duality has highly positive association with performance in low munificent and high complex environment

Baliga, Moyer and Rao (1996) studying the relationship between duality and firm performance presented opposite results. First, in this study, there is no significant difference in performance when the change in duality status occurs. Second, in the long term, there is no significant difference on the impact of duality and non-duality on firm performance. This paper also indicated that although the duality does change the managerial process change, it does not create more assets and as such fails to affect firm performance. The main finding of this research is very absolutely important for increasing value of company through improving governance because complexity of determinants which affect to performance.

\subsubsection{Board Independence and Firm Performance}

Baysinger and Butler (1985) (cited by Bhagat \& Black, 2000) suggested that the inside and outside directors have their own strengths. For the outsiders including affiliated directors, they could bring variety of skills and expertise to the board. For the insiders, they may be better in planning and making decisions. The mixability of board may lead to high performance. Klein (1998) conducted the research on the impact of inside and outside directors as proxies of board composition on firm performance. The study appreciated the role of inside directors in increasing stock return. Hermanlin and Weisbach (1991) approached instrument method to reject spurious relationship between dependent and independent variables in order to explore the difference on firm performance caused by board composition and director incentives. On the ground of an agency theory, Hermanlin and Weibach (1991) tested the impact of outside and inside directors on firm performance with many control variables relating to ownership of the board. The result indicated that there is no relationship between board composition and firm performance. The study suggested that the inside and outside directors affect equally on 
firm performance. Moreover, each board in each company has optimal structure including inside and outside directors, so it is difficult to expect that there is significant correlation between board composition and firm performance. The third interpretation for this result is the problem between residual of agency and residual of performance. All companies always do everything to reduce agency cost. The result is inconsistent with expectation that the outside manager highly associated with firm value. This study provided evidencepositive supporting between ownership concentration and firm performance. However, this influence is various across ownership level of top management and CEO.

\subsubsection{Ownership Concentration and Firm Performance}

Morck, Shleifer and Vishny (1988) presented the interesting results on the relationship between management ownership and market value of company. The management ownership includes share of top in a firm and market value is measured by Tobin's $\mathrm{Q}$. The main finding pointed out that Tobin's $\mathrm{Q}$ changes across different ownership level. When the percentage of share increases from $0 \%$ to $5 \%$, Tobin's $\mathrm{Q}$ also goes up. However, this figure goes down when the increase of ownership to $25 \%$ and then rises slightly again. With a similar view of significant impact of managerial ownership on firm performance, Short and Keasey (1998) in their study compared this relationship in two countries: U.S and U.K. They presented that in the U.K, the interest of shareholders and managers is aligned at low ownership but becomes entrenched at high level. In addition, they gave some evidences to prove the non-linear relationship between ownership and performance measured by accounting or market valuation method at low level share.

Cui and Mark (2003) undertook the research on a relationship between ownership and firm performance for companies having high level of research and development. Using Hausman test and 2SLS, they founded out that the W-shaped curve occurs representing the impact of managerial share on Tobin's Q. In addition, this study is the first one providing contrary result between accounting measure (ROA) and market value measure (Tobin's Q). It also emphasized the important role of industry on firm performance potentially and suggested that future research should control industry and firm size.

In summary, on a ground of the above analyses, this study forms an analytical framework, presented below, which will be used for empirical purposes.

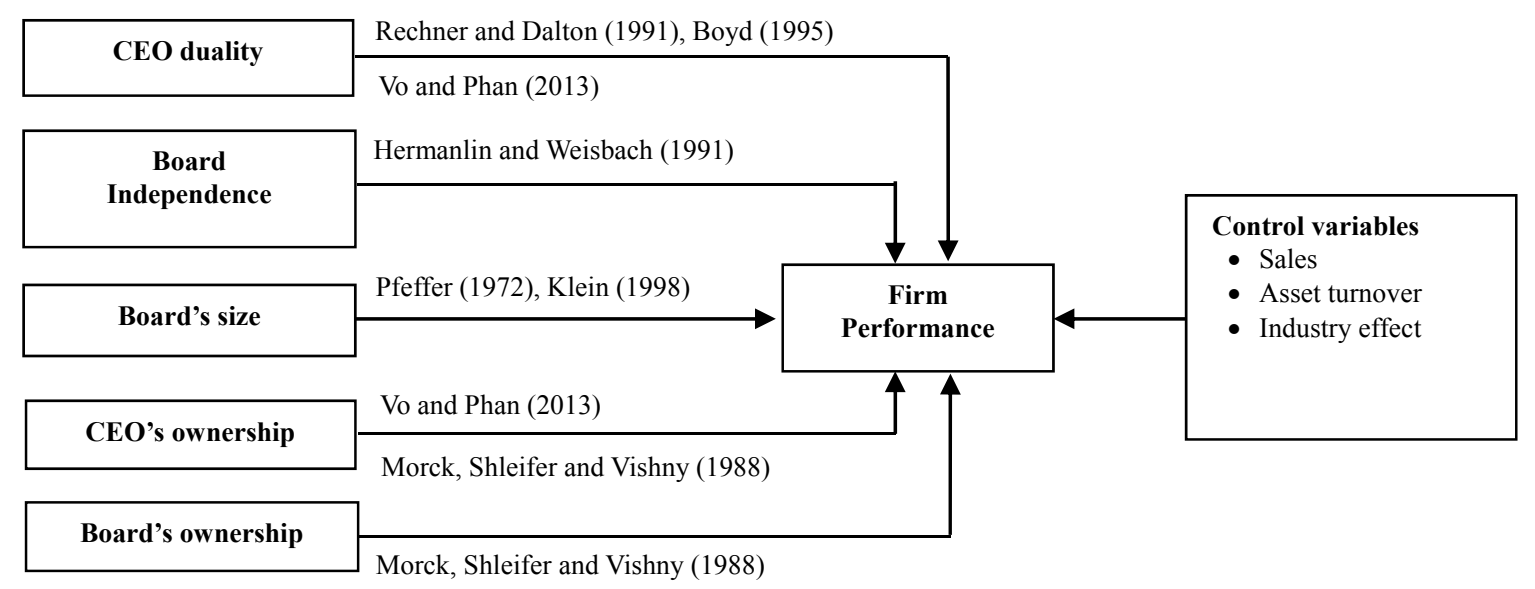

Figure 1. Analytical framework

\section{Data and Methodology}

\subsection{Data}

This study uses financial ratios, ownership, CEO duality and board composition from audited financial reports and annual reports of firms which are listed on Ho Chi Minh Stock Exchange (HOSE) from 2008 to 2012. However, due to missing information on a board of directors in the firms' annual reports, for the period from 2008 to 2012, 177 listed firms are selected and included in the sample. It is noted that financial institutions and banks are excluded from the dataset. 


\subsection{Variables}

\subsubsection{Dependent Variables}

In many studies, financial performance is measured by two methods based on accounting and market value. Joh (2003) in his research referred some reasons for choosing accounting method to measure performance. First, the market value just reflects the supply and demand of stock based on available information but this value does not present the actual circumstances of the company when stock market is inefficient. Second, accounting estimation is more directly concerned with profitability and firm's survival than market valuation. Third, using accounting in measuring performance is available with both unlisted and listed enterprises. In this study, various measurements are used to estimate firm performance including accounting, market value and a combination of the two.

\subsubsection{Accounting Measurement}

Various accounting measurements have been used to estimate firm performance. Return on asset (ROA) and return on equity (ROE) are calculated by the ratio between net income and total asset (for ROA) and total stockholder's equity (for ROE). The total asset and total stockholder's equity are estimated by average of beginning and ending figures in a financial year. These ratios are used in studies by Brown and Clayor (2004), Bhagat and Bolton (2008), Bhagat and Black (2000), Klapper and Love (2004). ROA and ROE indicate the effectiveness in using total asset and equity of firms. It means that two these ratios present the amount of net income being generated by one unit of total asset and equity respectively. All of the financial indicators relating to ROA and ROE estimation are taken from audited annual financial statements of firms.

\subsubsection{Market Value Measurement}

Tobin's $\mathrm{Q}$ is considered the most widely adopted financial ratio to measure firm's performance. This ratio was proposed by Brainard and Tobin (1968) with the original formula:

$$
Q=\frac{\text { market value of outstanding stock }+ \text { market value of debt }}{\text { replacement value of all production capacity }}
$$

This ratio has been widely used in empirical studies on corporate governance and firm performance including Bhagat and Bolton (2008), Bhagat and Black (2000), Klapper and Love (2004). In recent years, Tobin's Q ratio is modified (Bhagat \& Bolton, 2008) as follow:

$$
Q=\frac{\text { Total asset }+ \text { market value of equity }- \text { book value of equity }- \text { deferred taxes }}{\text { Total assets }}
$$

This approach of estimation will be used in the study because of the availability of information in financial statements and annual reports. For consistency of a dataset, an inversely market value of stock from other financial ratios is calculated. These are Price to earnings ratio (P/E) and Earnings per Share (EPS). P/E which is measured by market price over EPS indicates income allocated for one share. This ratio is estimated by:

$$
E P S=\frac{\text { net income }- \text { preferred stock dividend }}{\text { number of common stocks. }}
$$

Considering two values of these financial ratios, the market price of stock is then calculated as:

$$
\text { Market price }=P / E x \text { EPS } x \text { Number of common stock. }
$$

\subsubsection{The Mixed Measurement of Accounting Value and Market Value}

Because of the disadvantages of Tobin's Q ratio, accounting ratios have also been used. It is argued that only accounting or market value method cannot represent a good proxy for a firm performance. As a result, the so-called Z-score model is also used to measure performance. The model was developed by Altman (1968) to predict corporate bankruptcy. He presented that Z-score based on a set of financial ratios can be used to assess financial health of the firms. The advantage of Z-score is that the model uses the weight for scoring firm performance. The final discriminant model is as below:

$$
\text { Z-score }=0.012 X_{1}+0.014 X_{2}+0.033 X_{3}+0.006 X_{4}+0.999 X_{5}
$$

Where $X_{1}$ : working capital / total asset;

$X_{2}$ : Retained earnings / total assets;

$X_{3}$ : Earnings before interest and taxes/total assets;

$X_{4}$ : Market value equity/book value of total debt; 
$X_{5}$ : Sales/total asset;

Z-score: overall index;

i. For $\mathrm{X}_{1}$, working capital is the difference between current asset and current liability. This ratio measures a liquidity level for a firm. If this ratio is negative, it means that company is using short-term capital to finance long-term asset. It is a very risky practice in financial management.

ii. The second ratio, $\mathrm{X}_{2}$, measures the reinvestment level of firm from net income. A company with a higher ratio will better reflect an earning power in the future than the lower ratio firms.

iii. The ratio $\mathrm{X}_{3}$ indicates the operating efficiency.

iv. For $\mathrm{X}_{4}$, equity is referred to the common and preferred stock; and debt includes both short term and long-term debts. The number of common stocks is far greater than a number of preferred stock for a particular firm. As such, a market value of common stocks is used as a proxy for equity in this study. This ratio estimates a value of company based on available information on stock market.

v. The ratio $\mathrm{X}_{5}$ is called asset turnover. This presents the capacity of company in using assets to generate sales.

This study uses an initial sample of companies including two groups of bankrupt and non-bankrupt companies. It stressed the important role of Z-score in predicting the bankrupt probability of firm with high accuracy. The accurate level gets 94 percent of sample with 95 percent of all companies in two groups. Because of the high confidence in accessing the financial health of companies, Z-score is used as new measurement for firm performance compared to traditional estimation in previous studies.

\subsubsection{Independent Variables}

For corporate governance, in this study, board composition, structure and CEO characteristic are used as proxies. The relevant information is extracted from the annual reports of listed companies.

For a CEO characteristic: CEO-chairman duality and CEO's percentage ownership are used as the proxies. For duality, it is a binary variable which is one if CEO is also served as chairman and zero if not. This is the most common dependent variable used in many studies such as Richer and Dalton (1991), Baliga, Moyer and Rao (1996) or Boyd (1995). The ownership of CEO presents the voting right and relationship between interest of CEO and firm. It is included in the model in order to control CEO characteristic and to test the impact of ownership to firm performance. CEO's ownership is measured by percentage of share held by CEO.

For a board of director's structure and composition, this study uses board size, board independence and board ownership as the proxies. In theory, Zahra and Pearce (1989) referred board size in board composition. In practice, Bhagat and Bolton (2008) and Rosenstein and Wyatt (1990) considered that the important role of board size on firm performance. In addition, board independence is also taken into account in many empirical studies relating to firm performance and corporate governance. The independent level of board in this study is measured by the ratio between a number of independent members and the total members in the board. Circular 121/2012/TT-BTC of The Ministry of Finance stipulates that independent members must meet all requirements as follows:

i. They are non-executive members. The non-executive member is not director, vice-director, chief accountant or others who hold managerial positions which are appointed by board of directors.

ii. They are not member of the board, director, vice director of subsidies, cooperative companies which are controlled by listed company.

iii. They are not large shareholders or representatives and relatives of large shareholders.

iv. They do not work for law consultancy or auditing firms of listed company in the most recent two years.

v. They are not the suppliers or customers, which account for $30 \%$ of transaction values in the most recent two years.

For ownership concentration, it is also considered as important factor having significant influence on firm performance. In general on firm performance, Short and Keasey (1998) and Cui and Mark (2003) pointed out that the impact of ownership is very different across firms depending on ownership level. Therefore, in this study, ownership is also used as a proxy for corporate governance

\subsubsection{Control Variables}

In theory, Zahra and Pearce (1989) emphasized on the crucial responsibility of firm size to determine the relationship between corporate governance and firm performance. It is necessary to build management and 
director board which is suitable for firm size. In many empirical studies such as Bhagat and Black (1999), Cui and Mark (2003) and Abidin, Kamal firm size has become popular in controlling firm's specifications. Joh (2003) considered that firm performance is subject to financial leverage and size. In this study, sales and total asset turnover are used as the proxies.

Table 1. A summary all variables used in this study: definition and measurement

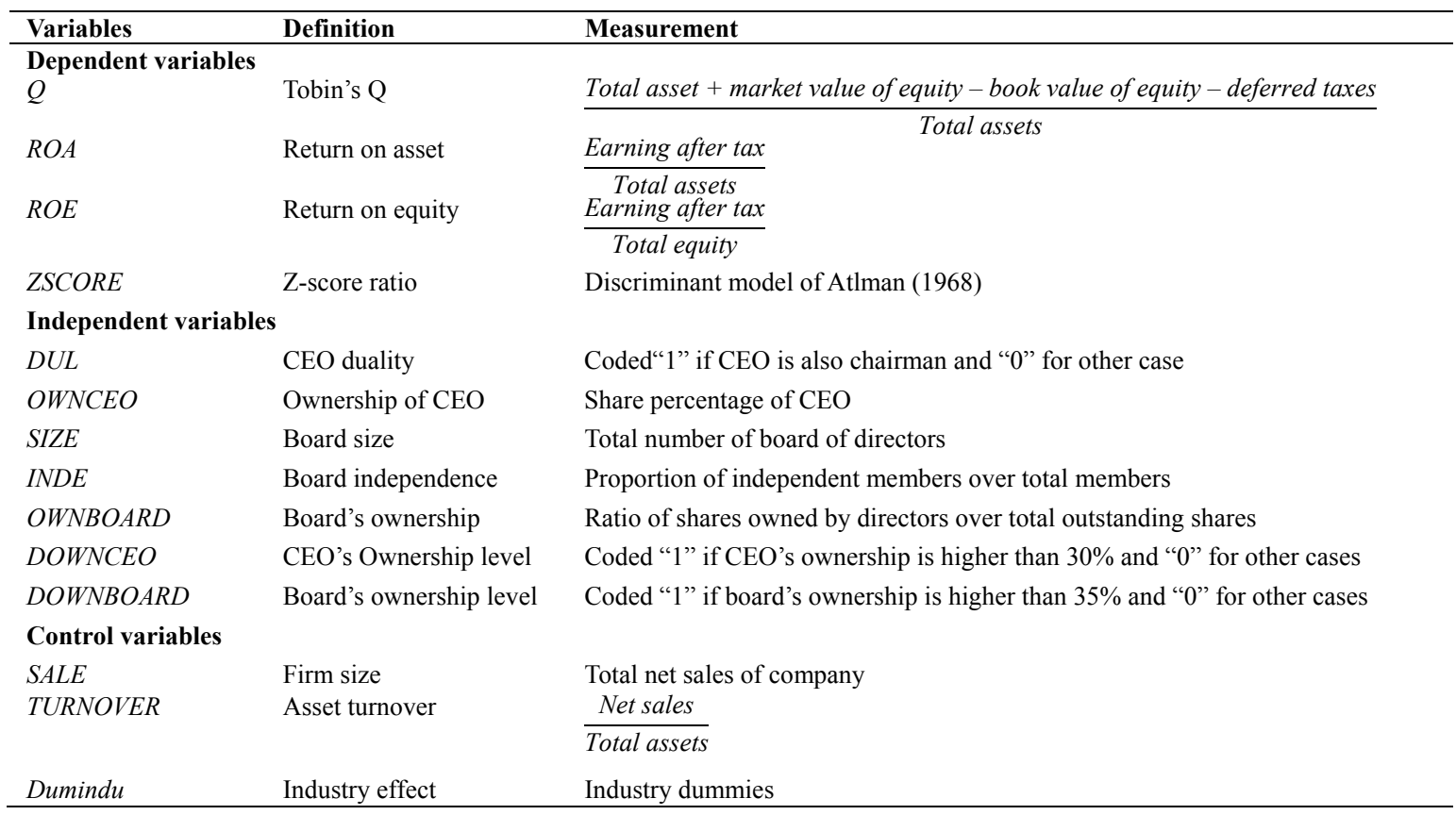

\subsection{Methodology}

This study uses OLS to regress the relationship between corporate governance and firm performance.

Model 1

$$
\begin{gathered}
R O A_{i, t}=\alpha_{0}+\alpha_{1} D_{U A L_{i, t}}+\alpha_{2} \mathrm{OWNCEO}_{i, t}+\alpha_{3} \operatorname{SIZE}_{i, t}+\alpha_{4} \mathrm{OWNBOARD}_{i, t}+\alpha_{5} I N D E_{i, t}+\alpha_{6} \mathrm{SALE}_{i, t}+ \\
\alpha_{7} \operatorname{OURNOVER}_{i, t}+\alpha_{8} \text { dumindu }_{i}+\varepsilon_{i, t}
\end{gathered}
$$

Model 2

$$
\begin{gathered}
\operatorname{ROE}_{i, t}=\alpha_{0}+\alpha_{1} \mathrm{DUAL}_{i, t}+\alpha_{2} \mathrm{OWNCEO}_{i, t}+\alpha_{3} \mathrm{SIZE}_{i, t}+\alpha_{4} \mathrm{OWNBOARD}_{i, t}+\alpha_{5} I N D E_{i, t}+\alpha_{6} \mathrm{SALE}_{i, t}+ \\
\alpha_{7} \operatorname{TURNOVER}_{i, t}+\alpha_{8} \text { dumindu }_{i}+\varepsilon_{i, t}
\end{gathered}
$$

Model 3

$$
\begin{gathered}
Q_{i, t}=\alpha_{0}+\alpha_{1} D U A L_{i, t}+\alpha_{2} \text { OWNCEO }_{i, t}+\alpha_{3} \text { SIZE }_{i, t}+\alpha_{4} \mathrm{OWNBOARD}_{i, t}+\alpha_{5} I N D E_{i, t}+\alpha_{6} \mathrm{SALE}_{i, t}+\alpha_{7} \text { TURNOVER }_{i, t} \\
+\alpha_{8} \text { dumindu }_{i}+\varepsilon_{i, t}
\end{gathered}
$$

Model 4

$$
\begin{gathered}
\operatorname{ZSCORE}_{i, t}=\alpha_{0}+\alpha_{1} \text { DUAL }_{i, t}+\alpha_{2} \mathrm{OWNCEO}_{i, t}+\alpha_{3} \operatorname{SIZE}_{i, t}+\alpha_{4} \mathrm{OWNBOARD}_{i, t}+\alpha_{5} I N D E_{i, t}+\alpha_{6} \mathrm{SALE}_{i, t}+ \\
\alpha_{7} \text { TURNOVER }_{i, t}+\alpha_{8} \text { dumindu } u_{i}+\varepsilon_{i, t}
\end{gathered}
$$

\section{Data Analysis and Empirical Results}

\subsection{Data Statistics}

Table 1 below presents characteristics of the dataset used in this study including number of observations, mean, standard deviation, max value and min value of independent and dependent variables. Table 1provides the overview about information of financial statement and corporate governance of listed companies on HOSE. 
Table 2. Descriptive statistic of variables

\begin{tabular}{llllll}
\hline Variable & Obs & Mean & Std. Dev. & Min & Max \\
\hline ROA (\%) & 752 & 8.243 & 9.340 & -31.723 & 95.212 \\
ROE (\%) & 752 & 15.899 & 16.205 & -96.965 & 116.291 \\
Q & 680 & 0.739 & 9.928 & -256.152 & 21.394 \\
ZSCORE & 736 & 1.681 & 3.103 & -2.681 & 33.017 \\
DUAL & 752 & 0.429 & 0.495 & 0 & 1 \\
OWNCEO (\%) & 752 & 6.734 & 12.936 & 0 & 72.852 \\
SIZE & 752 & 5.658 & 1.180 & 3 & 12 \\
OWNBOARD (\%) & 752 & 15.845 & 19.183 & 0 & 100 \\
INDE & 751 & 0.042 & 0.103 & 0 & 0.6 \\
SALE (thousand billion VND) & 752 & 1.62 & 4.11 & 0.343 & 68.3 \\
TURNOVER & 752 & 1.191 & 1.272 & 0.002 & 10.368 \\
\hline
\end{tabular}

ROA has a mean value of $8.243 \%$ with standard deviation of $9.340 \%$, while these figures are $15.899 \%$ and $16.205 \%$ respectively for ROE. Tobin Q ratio has a wide interval between min value $(-256.15)$ and max value (21.394) with the mean of 0.739. Similarly with Q, ZSCORE also presents low performance in Vietnamese listed firms on HOSE. It averages 1.681 with standard deviation of 3.103, while the min value is -2.681 and max value is 33.017. In general, the ownership level of CEO and the board has low value because the average values of them are $6.734 \%$ and $15.845 \%$, while maximum values are very high. The former is $72.852 \%$ and the latter is $100 \%$.

Table 3 below shows the correlation among dependent and independent variables. It can be clearly seen that there is no significant relation among explanatory variables. The maximum coefficient of correlation matrix is 0.71 via relationship between board's ownership and CEO's ownership. In addition, the VIF factor (Variance Inflation Factor) is also presented in Table 3. In general, the VIF factors are smaller than 10 and the maximum value is 2.4. It means that the model does not contain multicollinearity.

Table 3. Correlation matrix among variables

\begin{tabular}{|c|c|c|c|c|c|c|c|c|c|c|c|c|}
\hline Variables & 1 & 2 & 3 & 4 & 5 & 6 & 7 & 8 & 9 & 10 & 11 & VIF VIF \\
\hline (1) $\mathrm{ROA}$ & 1 & & & & & & & & & & & - \\
\hline (2) ROE & 0.86 & 1 & & & & & & & & & & - \\
\hline (3) $\mathrm{Q}$ & 0.06 & 0.06 & 1 & & & & & & & & & - \\
\hline (4) ZSCORE & 0.14 & 0.1 & -0.07 & 1 & & & & & & & & - \\
\hline (5) DUAL & 0.04 & 0.03 & 0.03 & 0.06 & 1 & & & & & & & 1.34 \\
\hline (6) OWNCEO & -0.11 & -0.07 & 0.02 & -0.11 & 0.44 & 1 & & & & & & 2.4 \\
\hline (7) SIZE & 0 & 0 & 0.03 & -0.09 & -0.01 & -0.07 & 1 & & & & & 1.04 \\
\hline (8) OWNBOARD & -0.11 & -0.04 & -0.01 & -0.1 & 0.19 & 0.71 & 0.03 & 1 & & & & 1.92 \\
\hline (9) INDE & -0.06 & 0 & -0.06 & -0.01 & -0.01 & 0.12 & 0.04 & 0.08 & 1 & & & 1.02 \\
\hline (10) SALE & 0.15 & 0.15 & 0.03 & 0.12 & -0.02 & -0.03 & 0.1 & -0.02 & 0 & 1 & & 1.04 \\
\hline (11) TURNOVER & 0.09 & 0.11 & 0.03 & 0.59 & 0.08 & -0.1 & -0.12 & -0.12 & 0 & 0.18 & 1 & 1.07 \\
\hline
\end{tabular}

\subsection{Regression and Discussion}

Table 4 below shows the test results for two most moderate problems in OLS regression models: heteroskedasticity and serial correlation. The panel A indicates that the all models contain heteroskedasticity because the Prob. Chi-Square is 0.000, whereas Panel B presents autocorrelation happens in equation (1) and (2). 
Table 4. Tests of heteroskedasticity and autocorrelation

\begin{tabular}{lllll}
\hline \multicolumn{4}{l}{ Panel A Breusch-Pagan / Cook-Weisberg test for heteroskedasticity } & \\
& Equation (1) & Equation (2) & Equation (3) & Equation (4) \\
\hline Chi-square & 90.180 & 6.530 & 5607.060 & 261.190 \\
Prob. > Chi-square & 0.000 & 0.010 & 0.000 & 0.000 \\
\hline \multicolumn{2}{l}{ Panel BBreusch-Godfrey LM test for autocorrelation } & & \\
& Equation (1) & Equation (2) & Equation (3) & Equation (4) \\
\hline Chi-square & 20.334 & 52.621 & 0.395 & 0.245 \\
Prob.> Chi-squared & 0.000 & 0.000 & 0.529 & 0.621 \\
\hline
\end{tabular}

Because of shortcomings of OLS model, Feasible Generalized Least Square (FGLS) is developed to regress a dependent variable on independent variables. Wooldridge (2002) considers that the FGLS is more suitable for panel date and has more advantages than pool OLS, even OLS with fixed effect or random effect (the two popular models in economic researches). The disadvantage of OLS is that the coefficient is bias if the model contains heteroskedasticity and/or autocorrelation. For OLS with random effect or fixed effect, the assumption of this model is that covariance between independent variables and the error term is zero. However, for FGLS, it gives better results than two above models in case of the presence of heteroskedasticity, serial correlation or non-zero covariance between independent variable and error term.

Based on empirical review in section 2, it is expected that there is a structural change in the relationship between managerial ownership and firm performance. Therefore, in order to test it, two dummy variables are included to control ownership level of CEO and board of directors. The system of models is as follows:

Model 5

$$
\begin{gathered}
\operatorname{ROA}_{i, t}=\alpha_{0}+\alpha_{1} \mathrm{DUAL}_{i, t}+\alpha_{2} \mathrm{OWNCEO}_{i, t}+\alpha_{3} \mathrm{SIZE}_{i, t}+\alpha_{4} \mathrm{OWNBOARD}_{i, t}+\alpha_{5} I N D E_{i, t}+\alpha_{6} \mathrm{SALE}_{i, t}+ \\
\alpha_{7} \text { TURNOVER }_{i, t}+\alpha_{8} \text { dumindu }_{i}+\varepsilon_{i, t}
\end{gathered}
$$

Model 6

$$
\begin{gathered}
R O E_{i, t}=\alpha_{0}+\alpha_{1} D_{U A L_{i, t}}+\alpha_{2} \text { OWNCEO }_{i, t}+\alpha_{3} \operatorname{SIZE}_{i, t}+\alpha_{4} \mathrm{OWNBOARD}_{i, t}+\alpha_{5} I N D E_{i, t}+\alpha_{6} \mathrm{SALE}_{i, t}+ \\
\alpha_{7} \operatorname{TURNOVER}_{i, t}+\alpha_{8} \text { dumindu }_{i}+\varepsilon_{i, t}
\end{gathered}
$$

\section{Model 7}

$$
\begin{gathered}
Q_{i, t}=\alpha_{0}+\alpha_{1} D U A L_{i, t}+\alpha_{2} \text { OWNCEO }_{i, t}+\alpha_{3} \text { SIZE }_{i, t}+\alpha_{4} \text { OWNBOARD }_{i, t}+\alpha_{5} I N D E_{i, t}+\alpha_{6} S_{A L E} E_{i, t}+\alpha_{7} \text { TURNOVER }_{i, t} \\
+\alpha_{8} d u m i n d u_{i}+\varepsilon_{i, t}
\end{gathered}
$$

\begin{tabular}{|c|c|c|c|c|c|c|c|c|}
\hline \multirow[b]{2}{*}{ Model } & \multicolumn{8}{|c|}{ Dependent variables } \\
\hline & ROA (1) & ROE (2) & Q (3) & ZSCORE (4) & ROA (5) & ROE (6) & $Q(7)$ & ZSCORE (8) \\
\hline DUAL & $1.726 * *$ & 1.533 & 0.635 & 0.133 & 0.755 & 0.283 & 0.943 & -0.049 \\
\hline OWNCEO & $-0.135 *$ & $-0.196 *$ & 0.039 & $-0.037 *$ & & & & \\
\hline SIZE & 0.232 & 0.409 & 0.426 & -0.076 & 0.331 & 0.536 & 0.387 & -0.057 \\
\hline OWNBOARD & $0.058 * *$ & $0.107 * *$ & -0.017 & $0.028 *$ & & & & \\
\hline INDE & -3.220 & 1.579 & $-7.767 * *$ & $3.804 *$ & -4.467 & -0.149 & $-7.558 * * *$ & $3.502 *$ \\
\hline SALE & 0.000 & 0.005 & 0.000 & 0.000 & 0.000 & 0.005 & 0.000 & 0.000 \\
\hline DOWNCEO & & & & & $-3.019 * * *$ & $-5.615 * * *$ & -1.123 & $-1.291 * *$ \\
\hline DOWNBOARD & & & & & $2.151 * *$ & $4.965 * *$ & 1.488 & $1.296 *$ \\
\hline TURNOVER & 0.864 & 1.846 & 0.123 & 0.851 & 0.979 & 2.006 & 0.141 & 0.872 \\
\hline dumindu & $\begin{array}{l}\text { Industry } \\
\text { control }\end{array}$ & $\begin{array}{l}\text { Industry } \\
\text { control }\end{array}$ & $\begin{array}{l}\text { Industry } \\
\text { control }\end{array}$ & $\begin{array}{l}\text { Industry } \\
\text { control }\end{array}$ & $\begin{array}{l}\text { Industry } \\
\text { control }\end{array}$ & $\begin{array}{l}\text { Industry } \\
\text { control }\end{array}$ & $\begin{array}{l}\text { Industry } \\
\text { control }\end{array}$ & $\begin{array}{l}\text { Industry } \\
\text { control }\end{array}$ \\
\hline
\end{tabular}

Model 8

$$
\begin{gathered}
\operatorname{ZSCORE}_{i, t}=\alpha_{0}+\alpha_{1} \text { DUAL }_{i, t}+\alpha_{2} \mathrm{OWNCEO}_{i, t}+\alpha_{3} \operatorname{SIZE}_{i, t}+\alpha_{4} \mathrm{OWNBOARD}_{i, t}+\alpha_{5} I N D E_{i, t}+\alpha_{6} \mathrm{SALE}_{i, t}+ \\
\alpha_{7} \operatorname{TURNOVER}_{i, t}+\alpha_{8} \text { dumindu }_{i}+\varepsilon_{i, t}
\end{gathered}
$$

Table 5. Results by using FGLS

Note. * denotes significant level at $1 \% ; *$ denotes significant level at $5 \% ; * * *$ denotes significant level at $10 \%$. 


\subsubsection{Impact of CEO Characteristic on Firm Performance}

Table 5 shows the CEO duality has positive correlation with firm performance measured by ROA with confident level at $95 \%$. Although in term of ROE, Tobin Q and Z-score model, duality does not show significant result, the sign of coefficient in all cases is positive. This result supports the stewardship theory in which the role of CEO as chairperson is emphasized to control firms more effectively. In particular, Davis, Schoorman and Donaldson (1997) explored the mechanism of duality's impact on firm performance. CEOs are interested in the intrinsic value including achievement and motivation, which are not influenced by market stock value. Moreover, being CEO as chairperson helps the CEO understand better on an entire business of company and makes more informed decisions. It explains a rationale for a positive correlation between the duality of the CEO and firm performance why dual situation associates positively with firm performance.

\subsubsection{Impact of Board Independence on Firm Performance}

For board composition, this study fails to provide evidence to support the relationship between board's size and firm performance in all four measures of firm performance. The findings from this study are different with those from previous studies including Eisenberg, Sundgren and Wells (1997) study which confirmed that there is a negative correlation between board size and firm performance and Muth and Donaldson (1998) stressed the role of board in reflecting the internal and external business environment. These studies also believed strongly that there exists an optimal size of board depending on the particular circumstance in each company because it shows the good complement between inside and outside directors. The finding from our study is similar with conclusion of Bhagat and Black (1999) who concluded that there is no persuadable evidence to confirm that an increase of board size enhances firm performance. It may be the case that, for the relationship between board's size and firm performance in Vietnam, board size does not reflect its role in managing companies. It has not caused any effects on firm performance.

For other explanatory variables - proportion of independent directors, there is a significant correlation between Tobin's Q and Z-score in two directions. For Tobin's Q, it is negative and for Z-score, it is positive. The significant level is $5 \%$ and $1 \%$ respectively. This result is similar with Klein (1998) study which appreciated the role of inside directors. Market value represents the reaction of investors to the change of information relating to corporate governance and firm performance. In the Vietnamese stock market, investors usually react negatively to the change in top-tiered management of companies because they assume that bad problems are the main causes for these changes. First, there is no complement and cooperation between executive and non-executive in the board. Second, the larger board size usually includes many independent members from larger shareholders. Because they are non-executive, they cannot understand the company's situation. However, in the empirical conclusion of this study with Z-score, the market value of stock is just one component of a set of financial ratios in estimating firm performance. In this case, the independent board indicates the positive relationship with firm performance as proxied by Z-score. This presents that finding that the board independence and firm performance are positively correlated when firm performance is proxied using accounting measures.

\subsubsection{Impact of Ownership Concentration on Firm Performance}

Model 1, 2 and 4 indicate that board's ownership has positive relationship with firm performance when the latter is proxied by ROA, ROE and Z-score. Particularly, the coefficient is very highly significant at $5 \%$ and $1 \%$. It is proved by negative coefficient of CEO's ownership in three measurements of firm performance: ROA, ROE and. The new finding in this research is that there is a structural change in the relation between managerial ownership and firm performance. Model 6, 7 and 8 present the positive effect of CEO's ownership on firm performance when percentage of share held by CEO is in range of $0 \%$ and $30 \%$. After that, the increase in ownership makes firm performance decrease slightly. In contrast, firm performance decreases when board's share increases from $0 \%$ to $35 \%$. However, at higher ownership level, the performance is enhanced.

For CEO's ownership, in Vietnam, the shares do not promote the CEO in managing and improving performance because percentage of share owned by CEO is relatively low. Moreover, the stock market in Vietnam from 2008 to 2012 indicates the distressed period following the global financial crisis in 2008/2009. As such, the profit from stock is not significant. In addition, the low ownership leads to the weak voting right of CEO in annual meetings of board of directors. This cannot stimulate the ability of CEO. However, this study suggests that it should keep CEO's ownership lower than 30\% because the CEO's ownership has negative effect on firm performance when share level is higher than $30 \%$. This conclusion is similar with the finding from Short and Keasey (1998) indicating the alignment of interest between $\mathrm{CEO}$ and firm performance at low level of share and entrenchment at high level.

For the board, the main finding of this study is an existence of a structural change between board's ownership 
and firm performance. In more details, the impact of this factor is contrary to CEO's ownership. It means that board's share is negatively affected on firm performance when ownership increases from $0 \%$ to $35 \%$ and then, firm performance increases when ownership increases. The interpretation for this relation is that on one hand, at a low level of ownership, the board of directors has made bad decisions. On the other hand, at a higher level, the results support the stewardship theory that Davis, Schoorman and Donaldson (1997) presented that board members act for firms' benefits when they have strong relation with firms through ownership. This decreases transaction cost and increases operating efficiency.

\section{Conclusions and Implications}

The main findings of this study present various effects of corporate governance on firm performance. First, the research supports a stewardship theory which confirms the role of CEO duality in which the CEO also serves as chairperson in improving firm performance. Second, the impact of CEO's ownership and board's ownership on firm performance is various across ownership level. Third, this empirical study fails to provide an empirical evidence to confirm the significant relationship between the board's size and firm performance. Final, the most interesting finding of this study is that the board independence, as measured by proportion of independent members, has different impacts on firm performance in different measures.

The empirical study suggests solutions for listed companies in enhancing firm performance through improving corporate governance. Based on the empirical results, the lessons for corporate governance are proposed. The listed companies should focus on the role of CEO in managing and monitoring companies. The CEO should ideally be as chairperson in the board. In addition, the study presents that a low level of ownership does not encourage the CEO to improve firm performance; as such, board of director should compensate CEO by shares rather than by cash. The ownership represents to the voting right. The CEO with higher voting right will make good decisions for firm performance. For board of director, its ownership should keep lower because at this level, the interests of board director and companies are aligned.

\section{References}

Abidin, Z. Z., Kamal, N. M., \& Jusoff, K. (2009). Board structure and corporate performance in Malaysia. International Journal of Economics and Finance, 1(1), 150.

Altman, E. I. (1968). Financial ratios, discriminant analysis and the prediction of corporate bankruptcy. The Journal of Finance, 23(4), 589-609. http://dx.doi.org/10.2307/2978933

Baliga, B., Moyer, R. C., \& Rao, R. S. (1996). CEO duality and firm performance what's the fuss. Strategic Management Journal, 17(1), 41-53. http://dx.doi.org/10.1002/(SICI)1097-0266(199601)17:1<41::AID-SMJ784>3.0.CO;2-\#

Bhagat, S., \& Black, B. (1999). The uncertain relationship between board composition and firm performance. The Business Lawyer, 921-963. http://dx.doi.org/10.2139/ssrn.11417

Bhagat, S., \& Black, B. (2000). Board independence and long-term firm performance. Unpublished paper, University of Colorado. Retrieved from http://leeds-faculty.colorado.edu/bhagat/bb-022300.pdf

Bhagat, S., \& Bolton, B. (2008). Corporate governance and firm performance. Journal of Corporate Finance, 14(3), 257-273. http://dx.doi.org/10.1016/j.jcorpfin.2008.03.006

Boyd, B. K. (1995). CEO duality and firm performance: A contingency model. Strategic Management Journal, 16(4), 301-312. http://dx.doi.org/10.1002/smj.4250160404

Brainard, W. C., \& Tobin, J. (1968). Pitfalls in financial model building. The American Economic Review, 58(2), 99-122.

Brown, L., \& Caylor, M. (2004). Corporate governance and firm performance. http://dx.doi.org/10.2139/ssrn.586423

Cui, H., \& Mak, Y. T. (2002). The relationship between managerial ownership and firm performance in high R\&D firms. Journal of Corporate Finance, 8(4), 313-336. http://dx.doi.org/10.1016/S0929-1199(01)00047-5

Davis, J. H., Schoorman, F. D., \& Donaldson, L. (1997). Toward a stewardship theory of management. Academy of Management Review, 22(1), 20-47. http://dx.doi.org/10.5465/AMR.1997.9707180258

Eisenberg, T., Sundgren, S., \& Wells, M. T. (1998). Larger board size and decreasing firm value in small firms. Journal of Financial Economics, 48(1), 35-54. http://dx.doi.org/10.1016/S0304-405X(98)00003-8

FPT Securities' Website. (2014). Retrieved from http://www.fpts.com.vn/ 
Hermalin, B. E., \& Weisbach, M. S. (1991). The effects of board composition and direct incentives on firm performance. Financial Management, 101-112. http://dx.doi.org/10.2307/3665716

Hillman, A. J., \& Dalziel, T. (2003). Boards of directors and firm performance Integrating agency and resource dependence perspectives. Academy of Management Review, 28(3), 383-396. http://dx.doi.org/10.5465/AMR.2003.10196729

HOSE's Website. (2014). Retrieved from http://www.hsx.vn/hsx/Default.aspx

Joh, S. W. (2003). Corporate governance and firm profitability evidence from Korea before the economic crisis. Journal of Financial Economics, 68(2), 287-322. http://dx.doi.org/10.1016/S0304-405X(03)00068-0

Klapper, L. F., \& Love, I. (2004). Corporate governance, investor protection, and performance in emerging markets. Journal of Corporate Finance, 10(5), 703-728. http://dx.doi.org/10.1016/S0929-1199(03)00046-4

Klein, A. (1998). Firm Performance and Board Committee Structure 1. The Journal of Law and Economics, 41(1), 275-304. http://dx.doi.org/10.1086/467391

Le Minh, T., \& Walker, G. (2008). Corporate governance of listed companies in Vietnam. Bond Law Review, 20(2), 6. http://dx.doi.org/10.2139/ssrn.1696313

Ministry of Finance. (2012). TT-BTC regulations for corporate govnernance at listed companies. Retrieved from http://thuvienphapluat.vn/archive/Thong-tu-121-2012-TT-BTC-quy-dinh-quan-tri-cong-ty-ap-dung-cho-con g-ty-dai-chung-vb145477.aspx

Morck, R., Shleifer, A., \& Vishny, R. W. (1988). Management ownership and market valuation An empirical analysis. Journal of Financial Economics, 20, 293-315. http://dx.doi.org/10.1016/0304-405X(88)90048-7

Muth, M., \& Donaldson, L. (1998). Stewardship theory and board structure a contingency approach. Corporate Governance An International Review, 6(1), 5-28. http://dx.doi.org/10.1111/1467-8683.00076

Nguyen, N. D. (2008). Corporate governance in Vietnam: regulations, practices and problems. Retrieved from http://www.sme-gtz.org.vn/Portals/0/AnPham/CORPORATE\%20GOVERNANCE\%20IN\%20VIETNAM. pdf

Pfeffer, J. (1972). Size and composition of corporate boards of directors. The organization and its environment. Administrative Science Quarterly, 218-228. http://dx.doi.org/10.2307/2393956

Prime Minister of Socialist Republic of Vietnam. (2007). Converting Hochiminh Stock Center into Ho Chi Cinh Stock Exchange. Retrieved from http://chinhphu.vn/portal/page/portal/chinhphu/hethongvanban?class_id=1\&mode=detail\&document_id=24 536

Rechner, P. L., \& Dalton, D. R. (1991). CEO duality and organizational performance. A longitudinal analysis. Strategic Management Journal, 12(2), 155-160. http://dx.doi.org/10.1002/smj.4250120206

Rosenstein, S., \& Wyatt, J. G. (1990). Outside directors, board independence, and shareholder wealth. Journal of Financial Economics, 26(2), 175-191. http://dx.doi.org/10.1016/0304-405X(90)90002-H

Short, H., \& Keasey, K. (1999). Managerial Ownership and the Performance of Firms Evidence from the UK. Journal of Corporate Finance, 5(1), 79-101. http://dx.doi.org/10.1016/S0929-1199(98)00016-9

Vo, H. D., \& Phan, B. G. T. (2013a). Corporate governance and firm performance: Empirical evidence from listed companies on Ho Chi Minh City Stock Exhange. UEH Journal of Economic Development, 275, 1-15

Vo, H. D., \& Phan, B. G. T. (2013b). Woman member in board of directors and firm performance: Empirical evidence from Vietnam. Banking Journal, 85, 21-30.

Vo, H. D., \& Phan, B. G. T. (2013c). The role of CEO duality, experience of board and growth opportunity on firm performance. Open University Journal, 3(31), 52-65.

Vo, H. D., \& Phan, B. G. T. (2013d). The relationship between corporate governance and firm performance. Unpublished paper, Ho Chi Minh City Open University.

Williamson, O. E. (1988). Corporate finance and corporate governance. The Journal of Finance, 43(3), 567-591. http://dx.doi.org/ 10.1111/j.1540-6261.1988.tb04592.x

Wooldridge, J. M. (2002). Introductory Econometrics: A Modern Approach (2nd ed.). South-Western College. 
Zahra, S. A., \& Pearce, J. A. (1989). Boards of directors and corporate financial performance A review and integrative model.

Journal of

Management,

$15(2)$,

291-334.

http://dx.doi.org/10.1177/014920638901500208

\section{Copyrights}

Copyright for this article is retained by the author(s), with first publication rights granted to the journal.

This is an open-access article distributed under the terms and conditions of the Creative Commons Attribution license (http://creativecommons.org/licenses/by/3.0/). 